\title{
PIRAMIDA CARROLL PADA PERUSAHAAAN DI \\ INDONESIA : STUDI PADA 3 PERUSAHAAN \\ PEMENANG CSR AWARD 2016
}

\author{
Temy Setiawan' \\ Ari Purwanti
}

IUniversitas Bunda Mulia, Jakarta

2 Universitas Islam As Syafiyah, Jakarta

INFO ARTKEL

Keyword:

CSR, Indonesia, sustainability, carroll's Pyramid, UNGC

\author{
A B S T R A C T
}

Currently, CSR disclosure to stakeholders in Indonesia has been done by many companies. Such disclosures are integrated in the annual report or produced as a report. Many motives underlie the disclosures. The purpose of this study is to describe the company's profile and CSR disclosure motives of the winning company of CSR Award Indonesia 2016 in accordance with the Carroll pyramid. Company's disclosures will be analysed using the 10 principles developed by the United National Global Compact (UNGC). This study will analyses the data of the three companies who won CSR Award Indonesia 2016 from 2011 to 2015 using the corresponding indicators which are in accordance to the 10 principles of UNGC. The source of data are financial reports and sustainability reports. Findings. The analyses on the three companies that become the object of analysis has disclosed sustainability information that is in accordance with the 10 principles of UNGC. When associated with the CSR disclosure motive based on Carroll pyramid, the company has economic, legal, and ethical motives. Philanthropicic motive is not much expressed. Another finding shows that the three companies being analysed are engaged in mining and automotive.

\section{N T I SAR I}

Saat ini pengungkapan CSR di Indonesia kepada pemangku kepentingan sudah mulai banyak dilakukan oleh perusahaan baik terintegrasi di dalam laporan tahunan maupun dalam laporan tersendiri. Banyak motif yang mendasari pengungkapan tersebut. Tujuan dari penelitian ini untuk mendeskripsikan prodil perusahaan dan motif pengungkapan CSR dari perusahaan pemenang CSR Award Indonesia 2016 sesuai dengan piramida Carroll. Pengungkapan perusahaan akan dianalisis dengan 10 prinsip yang dikembangkan oleh United National Global Compact (UNGC). Penelitian ini akan menganalisis 3 perusahaan pemenang CSR Award Indonesia 2016 dari tahun 2011 hingga 2015 dengan indikator yang sesuai 10 prinsip UNGC. Sumber data adalah laporan keuangan dan sustainability report. Tiga perusahaan yang merupakan objek analisis mengungkapkan informasi keberlanjutan sesuai dengan 10 prinsip UNGC. Apabila dikaitkan dengan motif pengungkapan CSR pada piramida Carroll, perusahaan tersebut memiliki motif secara ekonomi, legal dan etika. Motif filantropi tidak banyak diungkapkan. Temuan lainnya, tiga perusahaan yang dianalisis bergerak di bidang tambang dan otomotif. 


\section{PENDAHULUAN}

Isu mengenai CSR bukanlah isu yang baru. Isu ini telah diangkat sejak 1950 dan mulai berkembang pada awal 2000an (Porter and Kramer, 2002; Cannon, 2014). Masalah CSR yang terkait dengan keberlanjutan menjadi perhatian praktisi bisnis dan akademisi (Kotler and Lee, 2005, Mc Williams et al., 2006). Oleh karena itu, aktifitas CSR tidak hanya penting untuk dilakukan namun perlu juga dikomunikasikan kepada pemangku kepentingan mengingat tekanan pemangku kepentingan terhadap tanggung jawab sosial dan lingkungan perusahaan semakin tinggi(Wilmshurst and Frost, 2000; Deegan, 2002; Ahmad and Sulaiman, 2004; Palazzo and Richter, 2005; O'Riordan and Fairbrass, 2008).

Pengungkapan atas aktifitas tanggung jawab sosial (Corporate Social Disclosure - CSD) menjadi media komunikasi perusahaan dengan para pemangku kepentingannya (Walter, 2014; Lii and Lee, 20I2). Perusahaan menggunakan CSD untuk menunjukan motif CSR yang dilakukannya. CSD dapat dilakukan secara terintegrasi di dalam laporan tahunan (Neu, Warsame and Pendwell, 1998; Halme, Huse, 1997; Santema, Van De Rijt, 200I) atau melalui laporan tersendiri seperti laporan keberlanjutan (Gunawan, 20I5; Davis-Walling and Batterman, 1997; Williams and Ho Wern Pei, 1999; Line, Hawley and Krut, 2002; Yuen and Yip, 2002; Jenkins and Yakovleva, 2005). Oleh karena itu, penyusunan CSD menjadi hal yang penting bagi perusahaan dalam berkomunikasi dengan pemangku kepentingan. $\mathrm{Hal}$ ini dapat memberikan image perusahaan bagi pemangku kepentingan (Rae and Rouse, 200I).

NCSR menangkap hal ini sebagai sesuatu yang positif. Pada tahun 2016, NCSR mengumumkan pemenang CSR Award 2016 pada bulan Desember 2016. Penghargaan ini merupakan ke 6 kalinya sejak tahun 2010 diselenggarakan. Salah satu aspek penilaian adalah CSD di dalam laporan tahunan dan laporan keberlanjutannya.

Penelitian ini berupaya untuk menganalisis motif perusahaan dalam melakukan CSR berdasarkan pengungkapannya di dalam laporan tahunan dan laporan keberlanjutan. Subjek pada penelitian ini adalah tiga perusahaan pemenang CSR Award 2016 yang diumumkan pada bulan Desember 2016. Urgensi penelitian ini karena masih terbatasnya penelitian kualitatif yang menganalisis keterkaitan CSD dengan motif perusahaan menurut piramida Carroll (Carroll, 2006).

\section{TINJAUAN PUSTAKA}

Caroll (1979, 1991, 2006) menjelaskan bahwa terdapat empat motif pelaksanaan CSR terpusat pada tanggung jawab ekonomi, legal, etika dan filantropi.

\section{I) Tanggung Jawab Ekonomi}

Perusahaan sebagai organisasi bisnis harus mampu menciptakan nilai bukan hanya untuk mencapai laba perusahaan tapi juga harus meningkatkan ekonomi regional dan global. Pada tahap ini, Caroll (199I) sudah mengembangan tanggungjawab perusahaan bukan hanya pada kepentingan internal pemegang saham namun juga pada ekonomi level regional/ sectoral. CSR merupakan salah satu strategi perusahaan dalam pencapaian tanggung jawabnya terhadap ekonomi. CSR dipandang sebagai suatu biaya yang harus memiliki kontraprestasi bagi perusahaan. Secara jangka pendek, CSR harus memiliki nilai ekonomi bagi perusahaan: membantu pemasaran produk dan jasa, meningkatkan image perusahaan bagi pelanggan dan masyarakat. Apabila perusahaan dapat memenuhi ekspektasi laba bahkan melampaui maka tentunya perusahaan akan mampu membantu ekonomi sekitar, regional maupun global.

\section{2) Tanggung Jawab Hukum}

Motif lain dari pelaksanaan CSR adalah perusahaan berupaya untuk menghindari legal cost. Saat ini kesadaran atas pentingnya pelaksanaan CSR sudah merupakan tuntutan dari pemangku kepentingan. Pemerintah berupaya dalam mengeluarkan UU terkait eksplorasi lingkungan dan proteksi karyawan serta masyarakat. Selain adanya legal cost, tentunya terdapat sanksi sosial bagi perusahaan. Aktivitas CSR diharapkan dapat memenuhi ekspektasi pemangku kepentingan agar perusahaan tidak terkena sanksi ekonomi maupun sanksi sosial.

\section{3) Tanggung Jawab Etis}

Pada tahap lebih lanjut dari motif CSR adalah perusahaan ingin mencapai kebaikan bersama bagi seluruh pemangku kepentingan. CSR dijadikan alat perusahaan dalam menciptakan kesejahteraan bersama bagi sebagian besar orang (utilitarisme). Kebaikan ini 
tidak hanya bagi manusia namun bagi seluruh elemen kehidupan (paham ecosentric). Motif CSR dalam hal ini adalah langkah etis perusahaan yang tidak hanya terbatas pada pemenuhan tanggung jawab hukum.

\section{4) Tanggung Jawab Kebijaksanaan (filantropi)}

Tanggung jawab kebijaksanaan merupakan level tertinggi dari piramida Caroll. Dalam tanggung jawab filantropi, Caroll menempatkan bahwa perusahaan pada level ini menjalankan CSR bukan lagi pada kepentingan etika namun perusahaan melakukan hal yang lebih di atas etika. Perusahaan berjalan untuk kepentingan masyarakat dan lingkungan. Keberadaan perusahaan akan meningkatkan kualitas hidup. CSR perusahaan bukanlah sesuatu yang wajib namun CSR perusahaan adalah bagian dari masyarakat itu sendiri.

United Nations Global Compact (UNGC) United Nations Global Compact adalah inisiatif dunia untuk perusahaan yang mengedepankan keberlanjutan sebagai salah satu sasaran kinerja. Saat ini UNGC terdiri dari 13.000 peserta perusahaan dan pemangku kepentingan lainnya di lebih dari 170 negara. Sepuluh 10 prinsip yang menjadi fokus dari UNGC dan dikelompokan dalah 4 kategori: Hak asasi (prinsip I dan 2); tenaga kerja (prinsip $3-6$ ); lingkungan hidup (Prinsip 7 - 9) dan anti korupsi (Prinsip 10).

\section{METODE PENELITIAN}

Penelitian ini merupakan penelitian kualitatif deskriptif dengan memgambil 3 subjek penelitian adalah perusahaan pemenang CSR Award Indonesia 2016. Objek penelitian adalah laporan tahunan dan laporan keberlanjutan dengan periode pengamatan 20II sampai dengan 2015. Metode analisis yang digunakan adalah pendekatan deskriptif komparatif diantara ketiga perusahaan tersebut

\section{HASIL PENELITIAN}

Tabel I Deskripsi Perusahaan

\begin{tabular}{|l|l|l|l|}
\hline \multicolumn{1}{|c|}{ Deskripsi } & \multicolumn{1}{|c|}{ PT Adaro } & \multicolumn{1}{|c|}{ Petronas } & \multicolumn{1}{c|}{$\begin{array}{c}\text { PT Astra } \\
\text { Internasional }\end{array}$} \\
\hline $\begin{array}{l}\text { Kategori } \\
\text { Award }\end{array}$ & Platinum & Gold & Silver \\
\hline $\begin{array}{l}\text { Jenis } \\
\text { Industri }\end{array}$ & $\begin{array}{l}\text { Tambang } \\
\text { (Batu Bara) }\end{array}$ & $\begin{array}{l}\text { Tambang } \\
\text { (Minyak dan } \\
\text { Gas) }\end{array}$ & Otomotif \\
\hline $\begin{array}{l}\text { Tahun } \\
\text { Berdiri }\end{array}$ & 1982 & 1974 & 1957 \\
\hline $\begin{array}{l}\text { Listing di } \\
\text { BEl }\end{array}$ & 16 Juli 2008 & - & 4 April 1990 \\
\hline
\end{tabular}

Tabel I memberikan gambaran ketiga perusahaan yang menjadi subjek penelitian. PT Adaro sebagai pemenang dengan kategori Platinum; Petronas dengan kategori Gold dan PT Astra Internasional dengan kategori silver. Apabila diperhatikan dari tiga perusahaan di atas, masuk dalam kategori high density industry. $\mathrm{Di}$ Indonesia, perusahaan dalam kategori high density industry diwajibkan dalam melakukan CSR dan melakukan pengungkapannya. Peraturan yang mengaturnya antara lain: Limited Liability Company Regulation number 40 of 2007 which explains that companies which are directly involved in natural resources related activities must perform CSR and may be financed by the company on the basis of propriety and fairness. In addition, there is the CSR Regulation number 47 of 2012, which requires the company to disclose the CSR in its annual report and have it held accountable in a general meeting of shareholders. Regulation number 23 of 2010 also stressed that the company must conduct activities of empowerment and development of the surrounding communities affected by the company's operations and report to the local government periodically; Pasal I angka 7 Undang-Undang Nomor 5 Tahun 1984 tentang Perindustrian dalam pasal 21 UU Perindustrian \& Pasal 87 ayat I Undang-Undang No.35 Tahun 2009 tentang Perlindungan dan Pengelolaan Lingkungan Hidup.

Dari ketiga perusahaan di atas pun, tampak bahwa ketiga perusahaan tersebut sudah beroperasi lama lebih dari 30 tahun. Tentunya going concern perusahaan merupakan hal penting yang dipertimbangkan perusahaan dalam memperhatikan kinerja sosial dan lingkungan. Perusahaan yang listing di BEI hanya PT Adaro dan PT Astra Internasional, artinya pemeringkatan dalam CSR Award Indonesia tidak hanya terbatas pada perusahaan yang terdaftar di BEI.

\section{PT Adaro}

Pada pemenuhan prinsip UNGC, PT Adaro melakukan penilaian dan pengembangan kinerja karyawan secara objektif dengan mengabaikan faktor latar belakang karyawan seperti: religi, jenis kelamin dan etnis. Selain itu, PT Adaro secara sungguh-sungguh merespon terhadap perubahan regulasi pemerintah antara lain UU No 19 tahun 2012 mengenai hak asasi tenaga kerja. Meskipun di dalam perusahaan, tidak ada 
kebijakan khusus mengenai HAM, namun HAM tercermin di dalam visi dan misi perusahaan dan dituangkan di dalam kode etik yang ditandatangani bersama manajemen dengan karyawan dan pemangku kepentingan lainnya yang terkait. Pihak manajemen menyadari bahwa potensi pelanggaran HAM akan berdampak negative terhadap kelangsungan usaha jangka panjang.

Selain itu, perusahaan tidak mempekerjakan karyawan di bawah usia 18 tahun serta mengurangi penggunaan bahan peledak berbahaya. Hal ini tampak pada laporan keberlanjutan 2013 yang menjelaskan bahwa terjadi penurunan penggunaan pelumas bekas untuk peledakan di tahun 2013 sebesar 47.3 ribu kilogram, turun drastis dari 121.38 ribu kilogram di tahun 2012 .

Dalam mengatasi korupsi, tidak ada pelatihan khusus bagi manajemen maupun karyawan, namun upaya yang dilakukan perusahaan: pemantauan melalui kinerja internal audit dan kampanye "I LOVE MORE ADARO" yang menekankan pada integritas, meritokrasi, keterbukaan, rasa hormat, dan keunggulan. Semua karyawan diwajibkan untuk memahami dan menerapkan nilai-nilai ini, yang diharapkan dapat mencegah karyawan melakukan tindakan tercela, termasuk korupsi. Untuk mengidentifikasi risiko atau insiden korupsi, tim audit internal masuk langsung ke wilayah operasional di Wara, Tutupan, Paringin, Kelanis dan Dahai. Selain itu, perusahaan juga terbuka untuk laporan dari pihak luar mengenai tuduhan korupsi pegawai. Selama dua tahun terakhir, tim audit internal mengidentifikasi tiga insiden korupsi pegawai di Dahai. Dari ketiga insiden tersebut, dua terjadi pada tahun 2012 dan satu di tahun 2013. Ketiga kasus tersebut diakhiri dengan pemberhentian pegawai yang melakukan korupsi. Selain insiden korupsi pegawai, tim audit juga menemukan satu insiden korupsi yang melibatkan kontraktor, yang berakhir dengan penghentian kontrak.

Pada analisis lebih lanjut terkait dengan motif perusahaan menurut piramida Carroll, CSD dalam laporan tahunan dan laporan keberlanjutan banyak menjelaskan bahwa upaya perusahaan diarahkan pada pencapaian kestabilan ekonomi perusahaan untuk kelangsungan jangka panjang, pemenuhan regulasi pemerintah. Ranah etika yang tersentuh lebih kepada lingkungan hidup. Namun pengungkapan yang mengarahkan pada motif filantropi tidak ditonjolkan.

\section{Petronas}

Upaya yang dilakukan sejalan dengan prinsip UNGC berdasarkan pengungkapannya di dalam laporan tahunan dan laporan keberlanjutan 2012 sampai dengan 2015: menghargai hak penduduk lokal dalam memperoleh pekerjaan. Oleh karena itu program kemitraaan merupakan program unggulan dengan mengedepankan muatan lokal penduduk setempat, inklusi keahlian yang dibutuhkan, remunerasi pendapatan bagi penduduk lokal. Dengan adanya kerjasama yang baik dengan masyarakat lokal, maka diharapkan perusahaan dapat berkembang.

Selain itu pula pengembangan karyawan diberikan dalam bentuk pelatihan dan training. Seperti dijelaskan dalam laporan keberlanjutan 2014, Petronas memiliki program Employment Value Proposition (EVP) dalam hal pembinaan keterampilan dan pengembangan karier karyawan. Selain itu Petronas memiliki lembaga Pendidikan The Vocational Institution Sponsorship and Trainning Assistance (VISTA) yang telah didirikan sejak 1992 untuk membina tenaga terampil untuk industri MIGAS secara kontinu. Petronas menginvestasikan sekitar RM65.5 juta untuk program VISTA berkolaborasi dengan 22 lembaga kejuruan di bawah pemerintah federal dan berbagai instansi pemerintah negara bagian. Selain itu program lain di bidang pengembangan SDM, Petronas memiliki program Graduate Employability Enchancement Scheme (GEES) yang merupakan kemitraan antara pemerintah Malaysia dan perusahaan dalam memberikan bekal softskill dari para lulusan selama masa Pendidikan I tahun untuk menunjang karier di perusahaan dan posisi yang dipercayakan kepadanya. Pada tahun 2015, Petronas memperoleh penghargaan sebagai 100 perusahaan terkemuka Malaysia dalam The Graduate Employer of The Year Award 2015 karena perannya dalam meningkatkan kualitas SDM.

Terkait dengan lingkungan, sejak 20I I Petronas mengkampanyekan "I Hemat BBM" Program dilaksanakan oleh MISC untuk memantau dan mengurangi bahan bakar konsumsi serta 
mengurangi emisi $\mathrm{CO}_{2}$ oleh kapal-kapal armada di operasi. Selama periode laporan, MISC dihemat 4,52\% setara bahan bakar untuk 28.457 metrik ton (MT) dan emisi mencapai $\begin{array}{llll}\text { pengurangan } & 89.070 & \mathrm{MT} & \mathrm{CO}_{2}\end{array}$ diinvestasikan secara substansial di Green Technology untuk meningkatkan penghematan energi dan pengurangan emisi. Program ini telah memberikan kontribusi penghematan bahan bakar di atas sebesar 0,21\% atau pengurangan emisi $4103 \mathrm{MT} \mathrm{CO}_{2}$.

Analisis lebih lanjut terkait dengan motif pada piramida Carroll, secara umum tampak dalam CSD perusahaan 20II sampai 2015, CSR diarahkan pada pencapaian efisiensi biaya, etika dan filantropi melalui pengembangan human asset. Walaupun tidak banyak dijelaskan terkait dengan motif legal, namun Petronas comply dengan berbagai peraturan terkait. Petronas menunjukan arah yang jelas pada CSR kepada perbaikan kualitas manusia dan lingkungan secara berkesinambungan.

\section{PT Astra Internasional}

PT Astra Internasional di dalam CSD tampak memenuhi banyak prinsip yang sesuai dengan UNGC. Diantaranya, perhatian dalam masalah ketenagakerjaan yang didokumentasi secara jelas dan selaras dengan peraturan yang berlaku. Buku Peraturan Perusahaan PT Astra International Tbk 2012-2013 yang telah diperbaharui dan disahkan pada tahun $201 \mathrm{I}$ juga telah disosialisasikan kepada seluruh jajaran direksi dan karyawan Astra. Secara bersamasama, perangkat regulasi ini berfungsi menjaga agar tidak terjadinya praktik ketenagakerjaan yang tidak sehat seperti pekerja di bawah umur atau pekerja paksa serta diskriminasi dan penyimpangan etika/perilaku baik terhadap individu atau grup minoritas di lingkungan Grup Astra. Dengan hal tersebut, tingkat turnover karyawan Grup Astra dapat dikendalikan dengan baik, yaitu mencapai sebesar $4,2 \%$ sepanjang tahun 2011. Dari CSD perusahaan, PT Astra memiliki tingkat turnover sangat rendah untuk industri bisnis serupa. Dalam menjaga loyalitas karyawan, PT Astra melakukan Employee Opinion Survey (EOS) secara rutin setiap 2 tahun sekali. Disamping itu, acara rutin lainnya: Family Day/ Employee Gathering, kegiatan ekstrakurikuler di bidang olahraga \& seni yang ditujukan untuk menumbuhkan ikatan, rasa saling memiliki dan apresiasi yang kuat antara karyawan beserta keluarganya dan Perusahaan. Sejak tahun 2012, Astra mengungkapkan bahwa Sumber Daya Manusia yang handal menjadi salah satu penentu utama keberhasilan Astra sampai saat ini. Mengelola lebih dari 197.434 karyawan tentunya merupakan tantangan tersendiri bagi perusahaan. Namun dengan komitmen tinggi dari semua lapisan karyawan dengan filosofi "Winning Concept, Winning Sistem dan Winning Team," PT Astra Internasional yakin kualitas sumber daya manusia dapat terus ditingkatkan dan menunjang segala kegiatan dalam Strategic Triple Roadmap.

Selain itu, PT Astra sejalan dengan regulasi mengenai usia minimum tenaga kerja sehingga tidak ada tenaga kerja di bawah umur, memberikan upah minimal sesuai dengan UMR, tidak ada pembedaan ras/suku/ agama/gender dalam menentukan posisi dan memberikan pengembangan karier yang sama bagi semua karyawan sesuai kompetensi dan standar yang diatur. Program unggulan lainnya yang dikembangkan PT Astra tahun 2015: Astra Leadership Development Program AMDI menyelenggarakan peningkatan kompetensi mulai dari Astra Basic Management Program (ABMP), Astra First-line Management Program (AFMP), Astra Middle Management Program (AMMP), Astra Senior Management Program (AsrMP), Astra General Management Program (AGMP), Astra Executive Program (AEP) dan Astra Advanced Executive Program (AAEP). Integrated Talent Development (ITD).

Perhatian pada aspek lingkungan, dalam kurun waktu 2011 - 2012, keseluruhan program efisiensi TAM telah mencapai hasil di atas target, yaitu mengurangi penggunaan energi 3,3\% dan material kemasan 5,3\% serta emisi karbon 5,4\%. Bila dikuantifikasi efisiensi ini terwujud dalam bentuk penghematan 3.380 pohon, reduksi 35.27 ton $\mathrm{CO}_{2}$ dan penghematan biaya senilai Rp 4.8 miliar. Pada tahun 2014, Astra mengungkapkan bahwa Green Strategy tertuang dalam perencanaan Strategis Perusahaan yang mempertimbangkan aspek Environment, Health and Safety. Selama tahun 2014, Astra telah menetapkan kebijakan yang tertuang dalam Corporate Policy 2014 sebagai berikut: Penerapan Astra Green Company minimal BIRU untuk seluruh anak perusahaan, efisiensi sumber daya 
alam minimal sebesar $5 \%$ per satuan produk dibandingkan tahun 2013, melalui penerapan program cleaner production dan menggunakan renewable energy, melaksanakan efisiensi energi dan menurunkan Gas Rumah Kaca (GRK) 2\%, melaksanakan program Extended Producer Responsibility (tanggung jawab produsen terhadap dampak proses produksi dan produk yang dihasilkan), mengupayakan pemenuhan regulasi PROPER melalui "Road To be Green PROPER" dan pelaksanaan program Behaviour Based Safety (BBS) \& penerapan Contractor Safety Management System (CSMS) di internal perusahaan sebagai bagian program "Zero Workplace Accident". Pada tahun 2015 Astra mengungkapkan bahwa Astra Green Company (AGC) dibangun di atas konsep bahwa pada setiap pengambilan keputusan bisnis, manajemen yang secara sadar meletakkan pertimbangan perlindungan lingkungan, keselamatan \& kesehatan kerja (LK3) pemangku kepentingan. AGC merupakan perangkat asesmen Astra untuk memantau pencapaian kinerja perusahaan terhadap pilar sistem manajemen yaitu Green Strategy, Green Process, Green Product dan Green Employee serta pencapaian critical point di bidang Lingkungan, Kesehatan, dan Keselamatan Kerja (LK3) dan Kepatuhan Hukum.

Paparan di atas menjelaskan motif CSR perusahaan sudah sampai pada tahap filantropi yang menggambarkan bahwa peran perusahaan sebagai pelaku ekonomi akan menciptakan kebermanfaatan bagi masyarakat dan lingkungan. Perusahaan tidak hanya berupaya menjaga keberhasilan keuangan dengan efisiensi biaya, menaati regulasi hukum demi eksistensi maupun pada taraf etika sebagai entitas di tengah masyarakat namun juga berkontribusi dalam menciptakan kehidupan dan taraf hidup lebih baik.

\section{PENUTUP}

\section{Kesimpulan}

Penelitian ini memberikan gambaran mengenai profil perusahaan pemenang Indonesia CSR Award 2016. Dari ketiga pemenang untuk kategori platinum, emas dan silver, tampak bergerak di industri yang terkategori high density industry. Ketiga perusahaan tersebut merupakan perusahaan yang sudah lama berdiri lebih dari 30 tahun. Penelitian ini membuka celah penelitian lainnya, apakah perusahaan yang memperhankan going concern, dipengaruhi oleh kepercayaan pemangku kepentingan berdasarkan CSD. Perusahaan tersebut, dua diantaranya listing di BEI dan Petronas merupakan perusahaan asal Malaysia yang beroperasi di Indonesia. Dari ketiga perusahaan tersebut, sudah memenuhi standar keberlanjutan yang diungkapkan dalam 10 prinsip UNGC. Hal - hal yang sudah menjadi perhatian perusahaan pada aspek HAM, tenaga kerja dan lingkungan. Namun untuk pengungkapan anti korupsi masih tidak banyak dibahas baik di dalam laporan tahunan maupun laporan keberlanjutan.

Apabila dikaitkan dengan motif perusahaan dalam piramida Carroll, ketiga perusahaan tersebut menunjukan motif ekonomi, legal dan etika, namun belum pada motif filantropi.

\section{DAFTAR PUSTAKA}

Ahmad, N., \& Sulaiman, M. (2004). Environmental disclosure in malaysian annual reports: a legitimacy theory perspective. International Journal of Commerce \& Management, I4 (I), 44-58.

Carroll, A. B. 1979. A Three-Dimensional Conceptual Model Of Corporate Social Performance. Academy Of Management Review, 4, 497-505.

Carroll, A. B. |99|. The Pyramid Of Corporate Social Responsibility: Toward The Moral Management Of Organizational Stakeholders. Business Horizons, 34(4), 39-48.

Carroll, A.B. 1999. Corporate Social Responsibility: Evolution of a Definitional Construct. Business \& Society, Vol. 38, No. 3, 268-295.

Carroll, A. B. 2016. Carroll Pyramid Of CSR: Talking Another Look. Carroll International Journal Of Corporate Social Responsibility Vol. I No.3.

Carroll, A. B., \& Buchholtz, A. K. (2000). Business and society: ethics and stakeholder management (4th ed.), Cincinnati, $\mathrm{OH}$ : South-Western College Publishing.

Cannon, T. (20I2). Corporate responsibility 2nd edition. England: Pearson.

Colleoni, E. (2013). CSR communication strategies for organizational legitimacy in social media. Corporate Communications: An International Journal, Vol. I 8 No. 2, pp. 228-248. 
Davis-Walling P, Batterman S. (1997). Environmental reporting by Fortune $\mathbf{5 0}$ firms. Environmental Management; 2 ( (6): pp. 865-875.

Deegan, C. (2002). The legitimising effect of social and environmental disclosure - a theoretical foundation. Accounting, Auditing \& Accountability Journal, 15(3), 282-343.

Garriga, E., and Mele, D. (2004). Corporate social responsibility theories: mapping the territory. Journal of Business Ethics, 53:5I-7I.

Gunawan J. (20I5). Corporate social disclosures in Indonesia: stakeholders' influence and motivation. Social Responsibility Journal. Vol. II Iss 3: pp. 535 $-552$

Halme M, Huse M. (1997). The influence of corporate governance, industry and country factors on environmental reporting. Scandinavian Journal of Management I3(2):pp.137-I57.

Kotler P., Lee, N. (2005). Corporate social responsibility: doing the most good for your company and your cause. John Wiley \& Sons, Inc: Hoboken, New Jersey.

Li, X. G., Wang, X., \& Cai, J. Y. (20II). Corporate-, product-, and user-image dimensions and purchase intentions: the mediating role of cognitive and affective attitudes. Journal of Computers, 6(9), | 875-1879.

Lii, Y. and Lee, M. (20I2), Doing right leads to doing well: when the type of csr and reputation interact to affect consumer evaluations of the firm. Journal of Business Ethics, Vol. 105(I), Pp. 69-8I.

Line M, Hawley H, Krut R. (2002). The development of global environmental and social reporting. Corporate Environmental Strategy 9(I): pp.69-78

McWilliams A., Siegel, D. S., Wright, P. M. (2006). Corporate social responsibility: strategic implications. Journal of Management Studies 43(I): I-18.

Michelon, G. (20II), Sustainability disclosure and reputation: a comparative study. Corporate Reputation Review, Vol. 14 (2), pp. 79-96.

Neu P, Warsame H, Pendwell K. (1998). Managing public impressions: environmental disclosures in Annual Reports. Accounting, Organizations and Society 23(3):pp.265-82.
O'Riordan L, Fairbrass, J. (2008). Corporate social responsibility (CSR): models and theories in stakeholder dialogue. Journal of Business Ethics 83(4), Pp. 745758.

Othman, S., Darus, F. and Arshad, R. (20II), The influence of coercive isomorphism on corporate social responsibility reporting and reputation. Social Responsibility Journal, Vol. 7 (I), Pp. II8-I35.

Palazzo, G., Richter, U. (2005). Business as usual? The case of the tobacco industry. Journal of Business Ethics 6I (4), PP. 387-40I.

Pérez, A. (20I5). Corporate reputation and CSR reporting to stakeholders gaps in the literature and future lines of research. Corporate Communications: An International Journal, Vol. 20 (I), Pp. II 29

Porter, M. E., Kramer, M. R. (2002). The Competitive advantage of corporate philanthropy. Harvard Business Review. December, pp. 57-68.

Porter, E. M., \& Kramer, M. R. (2006). Strategy \& society: the link between competitive advantage and corporate social responsibility. Harvard Business Review, December, pp. 78_92.

Porter, E. M., \& Kramer, M. R. (20II). Creating shared value. Harvard Business Review, January-Februari, 2-17.

Raar, J. (2002). Environmental initiative: towards triple bottom line reporting. Corporate Communications: An International Journal, 7(3), 169-183.

Rae M, Rouse A. Mining Certification Evaluation Project - independent certification of environmental and social performance in the mining sector. A WWF-Australia discussion paper 200I. Resources Conservation Program, Mineral Resources Unit (WWF Australia), $200 \mathrm{I}$.

Santema S, Van De Rijt J. (200I). Strategy disclosure in Dutch Annual Reports. European Management Journal 19(1):pp.101-108.

United Nations. (2007). Indicators of Sustainable Development: Guidelines and Methodologies, Third Edition, UN Sales Publication No.E.08.II.A.2 (New York, December 2007).

Yuen CP, Yip D. (2002). Corporate environmental reporting e the CLP 
Power experience. Corporate Environmental Strategy 9(I):pp.95-100.

Walter, B. L, (20/4). Corporate Social

Responsibility Communication: Towards a Phase Model of Strategic Planning In Communicating

Corporate Social Responsibility: Perspectives and Practice. Published online: 25 Sep 20I4; 59-79.

Williams SM, Ho Wern Pei CA. (1999). Corporate social disclosure by listed companies on their web sites: an international comparison. The International Journal of Accounting 34(3):pp.389-4I9.

Wilmshurst, T. D., \& Frost, G. (2000). Corporate environmental reporting: a test of legitimacy theory. Accounting, Auditing \& Accountability Journal, I3(I), 10-26. 